State of mind, state of order

\title{
Reactions to ethnic unrest in the Islamic Republic of Iran
}

Elling, Rasmus Christian

Published in:

Studies in Ethnicity and Nationalism

Publication date:

2008

Document version

Early version, also known as pre-print

Citation for published version (APA):

Elling, R. C. (2008). State of mind, state of order: Reactions to ethnic unrest in the Islamic Republic of Iran.

Studies in Ethnicity and Nationalism, 8(3), 481-501. 


\title{
STATE OF MIND, STATE OF ORDER Reactions to Ethnic Unrest in the Islamic Republic of Iran
}

\author{
Rasmus Christian Elling \\ University of Copenhagen, Denmark
}

\section{NOTE:}

\section{This is author's pre-print version. The article has been published and reference should be made to the published version:}

Elling, Rasmus Christian. 2008. 'State of mind, state of order: Reactions to ethnic unrest in the Islamic Republic of Iran', Studies in Ethnicity and Nationalism, Vol. 8, No. 3: 481-501.

\begin{abstract}
By analysing the symbols and language employed in official statements on two cases of ethnic minority unrest in Iran in 2005-6, the article shows how the Islamic Republic's ideolo- gues and leaders are responding to threats against national security and to alternative definitions of identity. In this emerging discourse, religious and secular notions of patriotism and loyalty are interwoven and an Islamist/nationalist conceptualisation of Iranian nationhood is defended. This interesting process of paradoxical dynamics is an important part of the ongoing struggle to define the identity of Iran in a region boiling with political and cultural conflicts.
\end{abstract}

\begin{abstract}
Article
By examining the reactions of the leaders of the Islamic Republic to two cases of ethnic minority protest in the Iranian provinces of Khuzestan and Azerbaijan in 2005-6, this article aims to demonstrate how loyalty to the official definition of nationhood is formulated and defended through interconnected notions of territorial integrity and ideological commitment. The official response to the ethnic unrest was shaped by a careful approach, which sought not to reject the protestors by simply dismissing their grievances altogether. However, it was also used to warn Iranian citizens against perceived plots allegedly threatening the integrity of the nation-state. Thus, the official reaction is a case study of the two-pronged strategy of repressing dissent and accommodating the conformists, and of the way the leaders perceive the Iranian nationstate / the Islamic Republic as both a territorial-political and spatial entity as well as a cultural-historical and temporal entity being threatened by outsiders, traitors and counter-revolutionaries.
\end{abstract}

An analysis of the language employed in statements by Iran's rulers in dealing with incidents of ethnic unrest presents an interesting study in the protean ideology of the establishment and in the processes of inclusion and exclusion that shape the political project that is the Islamic Republic. While Iran certainly falls outside of the theoretical 
category of 'democracy', the current, official concept of national identity is nonetheless the product of the clashing dynamics of a complex, modern state and society, and by no means the result of a monolithic or medievalist theocracy, which might be the conclusion one could draw from the global media portrayal of Iran. Iranian leaders import notions of both an inclusive, civic democracy and of an exclusivist, Islamist system into their discourse and combine them in a conceptualisation of nationhood that utilizes both non-religious nationalist and religious sentiments. The official response to the cases of ethnic unrest discussed in this article shows how these sentiments are employed symbolically in state rhetoric. It also reveals how the issue of (inherent and/or provoked) ethnic conflict is at the heart of a potential or emerging conflict over the identity and future of Iran and Iranians, and therefore of great concern to those in power in Tehran and, indeed, also in many Western capitals.

\section{A notion of nation}

The Islamic Republic of Iran derives its legitimacy and authority from two sources: a) The will of the people as expressed in their active political participation (i.e. civic, popular participation, yet without a system qualifying for the label of representative democracy); and b) from God via the prophets and the Shiite Imams, the clergy and finally the Supreme Leader (i.e. religious yet without being a full-fledged theocracy due to its quasi-democratic constitutional mechanisms). Iranian state leaders demand from the citizens an ideological commitment not only to the Iranian state as a legal-territorial nation-state but to 'the Holy Order of the Islamic Republic' (nezâm-e moqaddas-e jomhuri-ye eslâmi), which makes Iran more than 'just' a republic in its 'Western' sense. This study is thus founded on the simple premise that the Islamic Republic's leaders in their discourse borrow heavily from both 'Western' and 'Islamic-flavoured' notions of nationhood and nationalism (1).

While the Islamic Republic's foundational, ideological discourse was that of universal and borderless Islamist revolution, today the nationalist element seems to be increasingly emphasized in the official conceptualization of Iranian nationhood (2). As has been pointed out (Paul 1999), there are several reasons for the change in the ideological mainstays of the Islamic Republic towards a more nationalistic stand, but the most important were the Iran-Iraq War of 1980-88, the unsuccessful project of exporting the Islamic Revolution and the isolated position Iran quickly took (or was forced into) on the world scene after the revolution in 1978-9. The war presented the Islamist leaders with the problem of legitimizing a war against a Muslim neighbour and Khomeini and his allies utilized both nationalist and religious sentiments to drum up support for the war by portraying Saddam Hussein not only as a puppet for Western and 'Zionist' powers but also as a traitor to Islam and a threat to the Iranian nation and 'fatherland' (see for example Menashri 2001). Hussein's being a Sunni furthermore added to the religious justification for the war in an overwhelmingly Shiite Iran. The war was thus an immediate brake on the earlier internationalist drive of the revolution: When even a Muslim neighbour (supported by many Muslim states) would attack Iran, the prospects of extending the revolution looked bleak.

Thus, while leaders such as the current President Ahmadinejad champion 'idealist' causes such as the Palestinian struggle, scholars tend to agree that, particularly since the 
death of Khomeini, Iranian foreign policy has been balanced by some 'realist' goals of national interest rather than just far-fetched ideological goals (Takeyh 2006, Ansari 2006, Ahmadi 2008) and that nationalism is becoming as important as Islamism in state ideology and domestic policy (Amirahmadi 1996). Despite several layers of ideological propaganda, it seems that the political leadership at its core has realized that the strong nationalist sentiment (which is shared by many or even most Iranians, whether they support the Islamic Republic or not) is at least as important an instrument as the religious for preserving the republic. In this respect, there are even signs that the Islamic Republic's leaders are keeping alive the Pahlavi state's conception of an 'eternal Iranian state' that pre-dates Islam. This is mirrored in the account of national history, which is promoted by the Islamic Republic's leaders through the formal education system (Ram 2000).

At the same time, since the mid 1990's, a wave of reformist and pro-democratic activity has helped embolden voices promoting ethnic minority rights, and thus opened a Pandora's Box of complex and sensitive issues in the discussion of Iranian national identity. Non-Persian ethnic minorities such as Azerbaijanis, Kurds, Baluchis, Lurs, Arabs and Turkmen make up at least half of Iran's population, many of whom live in the less developed periphery. The end of the Iran-Iraq War, the death of Khomeini, the more moderate line of President Rafsanjani (1989-97), and, most importantly, the reformist governments of President Khatami (1997-2005) have all contributed to what might be called a wave of ethnic mobilisation, including renewed interest in minority languages, cultures and rights (3). Ethnicity as a problematic issue was generally considered taboo during the rule of Khomeini, who allegedly saw ethnicity as a figment of 'Western' perceptions and a tool for Imperialist 'divide-and-rule' strategies (Atabaki 2005: 38)(4). However, the sudden easing of restrictions on public debate that followed the reformist presidential victory in 1997 has created an atmosphere much more open to discussions of minority rights. Thus, recent years have seen Iranian leaders directly addressing these issues, and even targeting specific minorities during election campaigns. Politicians have incorporated the issue of economic and infrastructural underdevelopment in ethnic minority areas into their populist rhetoric, and the President has toured far-flung provinces extensively, promising to use Iran's oil wealth on developing these areas.

However, it also seems that this relaxation, coupled with signs of general discontent in Iran, has contributed to an increase in more radical demands among ethnic minorities for cultural autonomy, economic development and increased power in local and national institutions. While these demands are often difficult to articulate in the heavily censored Iranian press, they have recently been formulated through or during spontaneous protests and turmoil. In the period 2005-7, reports of ethnic unrest reached world media, and forced the power establishment to articulate an answer that would reflect the official line toward this complex issue. Some minority spokesmen claim that the state is marginalizing the non-Persians and the Sunnis; and on the other hand, the government claims that the unrest is the result of foreign powers' manipulation, and thus a threat to the integrity of the Iranian nation. By conflating the ethnic groups' demands for greater autonomy with conspiracies to break up Iran, leaders are utilizing historical fears in Iran and thus demonizing proponents of minority rights; and, at the same time, ruling 
ideologues seek to portray the ethnic minorities as inseparable segments of a harmonious, multicultural and eternal nation-state. This is the core site of conflict within the politics of ethnicity in Iran today.

It is not the intention of this article to analyze the general economic, social or political status of ethnic minorities in Iran, nor is it aimed to judge whether the reaction of the officials and their condemnation of foreign powers is legitimate or realistic. Indeed, with the major power rivalry in the region nothing should be counted as impossible and no accusation can easily be dismissed - however, such issues are beyond the scope of this article. Furthermore, the status of non-Persian languages such as Azeri Turkish and Arabic is a very interesting and relevant topic, which deserves its own separate study. So, knowing that this article will open a mass of related questions and paths for further research, this text will rather aspire to analyze certain official statements in relation to particular events and thus to contribute to a more nuanced understanding of the Iranian state's ideological discourse today.

\section{The case studies}

In the following I will show how Iranian political leaders through newspapers reacted to two cases of ethnic unrest in 2005-6. For the purpose of this article 'leaders' and 'officials' are used to denote ministers, MPs, government spokespersons and highranking clerics, and all sources are gathered on the Internet, where most Iranian newspapers are uploaded daily. All quotations are translated from the original Persian by the author. This study is an aspect of a wider research project on ethnic unrest in Iran in the last four years, spanning ethnic groups living in as varied surroundings and circumstances as the Kurds, Arabs, Azerbaijanis and Baluchis, and such varied forms of 'unrest' as spontaneous riots, organized demonstrations, guerrilla attacks and terrorist bombings. In order to limit and focus this article, only two incidents have been chosen.

The first, which will be called the Ahvaz unrest, took place in the south-western Iranian province of Khuzestan, which borders Iraq, and in particular in the regional capital of Ahvaz. Apart from harbouring the bulk of Iran's oil industry, a significant part of the local population belong to the Arab minority. While there are no reliable statistics available on the ethnic composition in Iran, it is safe to say that they make up a large segment of Khuzestan's population, and that they - despite being Arabic-speakers and ethnically Arab - have been a part of the Iranian society and state at least since the Qajar era of 1781-1925. The second case, which will be called the Tabriz unrest, primarily took place within the two Azerbaijan provinces of north-western Iran (not to be confused with the independent republic of Azerbaijan), and in particular in the main city of Tabriz. Here, the majority of the population are - like their co-ethnics in the north - Azerbaijanis, a Turkic-speaking people who have since medieval times been an integrated part of Iranian society. Azerbaijanis are by far the largest minority in Iran, and might constitute more than 1/4 of the population. In 1945-6, regional autonomy was achieved with Soviet support in the short-lived Republic of Azerbaijan. Despite this, the Azerbaijanis are often portrayed as the best-assimilated ethnic minority in Iran, and they are seen as having played an important role in the Iranian state at least since the $16^{\text {th }}$ Century. 
From April 15-18, 2005 there was rioting and clashes between protesters and security forces in Ahvaz. The riots were apparently triggered by the distribution of an allegedly forged letter signed by a close aide to the then President Khatami (Kayhân 2005a). The letter called for relocation of the local Arab population in favour of ethnic Persians. Combined with the coverage in Arab media of an exiled separatist group's demand for 'independence' from 'the Persian occupiers', the letter caused uproar and resulted in bloody clashes. During the riots, reports - as they tend to do during social and political protests in Iran - differed greatly on the number of casualties, varying from two to twenty-nine people. The demand for increased autonomy is not in itself new: indeed, radical political groups in exile have before claimed that Khuzestan is 'occupied' by Persians, and that the area should become an independent Arab emirate or republic. Some ethnic activists claim to have endured historical oppression at the hands of a Perso-chauvinist Iranian state, and that they are suffering from unemployment, despite the fact that the province is home to abundant natural resources. Oil wealth is channelled back to Teheran, they claim, and the original inhabitants are left in poverty. Other ethno-political activists are by no means separatists, and simply demand economic development and cultural rights. The province has a history of ethno-political activity, although the Ahvaz turmoil of 2005 is by far the severest unrest in the area since the Islamic Revolution.

On May 12, 2006, the state-run newspaper Irân published a caricature, which showed a boy trying to communicate with a cockroach, who replies with the Azeri Turkish question namana? ('What?'). The cockroach being seen as the 'lowest' of all animals, the conclusion was reached by many that this was a racist joke meant to harm the ethnic identity of Azerbaijanis, who are often ridiculed in Persian-language humour. This alleged insult to the Azerbaijani-speakers lead to widespread demonstrations and rioting, in particular in the Azerbaijan provinces. As mentioned, Azerbaijanis are generally considered well integrated, and the riots seem to have taken Iranian leaders by surprise. Furthermore, the unrest and the slogans used during the demonstrations clearly showed that many Azerbaijanis feel insulted not only by the drawing, but also by what is perceived by some as the economic and political marginalization of non-Persians outside the capital. Although by no means the poorest area of Iran, some Azerbaijani activists claim that the central government will not spend sufficient resources on developing the northwest. On top of this, recent years have seen an increased demand for cultural rights, such as the right to teach Azerbaijani in public schools.

In order to identify the main themes in the exclusivist discourse of the leaders during these crises, I have chosen to roughly divide the responses into two categories. The first is concerned with the threats to the territorial integrity of Iran, which is perceived as a battle between 'real' Iranians against 'alien' (bigâne) forces, 'foreign agents' ( 'âmel-e khâreji), 'the identity-less' (bi-hoviyyat) and those paid off by foreign powers (mozdur). In this category, the Iranian leaders are playing on nationalistic registers well known to most Iranians, that is, the feeling of being exposed throughout history to foreign powers and their selfish interests. This fear is reflected in Iranian popular history which generally tends to portray 'Iran' as a nation-state that has been violated throughout a (rather problematic and unhistorical) chronology that might include as distant events as the invasions of Alexander the Great, the Arabs and the Mongols, and certainly will 
include and emphasize the role of colonialist European powers in Iranian politics as well as the 'neo-Imperialist' American agenda in the Middle East. Such crucial historical events as the Anglo-Soviet invasion of Iran in 1941, the CIA-sponsored coup against the nationalist Prime Minister Mosaddeq in 1953 and the animosity between Iran and the West since the Islamic Revolution in 1978-79 are particularly important to keep in mind when analyzing the current state rhetoric. The fear of conspiracies (Abrahamian 2005) is indeed detectable in many aspects of this rhetoric, and in particular in condemnations of domestic unrest.

The second category carved out for this purpose is the issue of ideological commitment to the religious-political project that is the Islamic Revolution and Republic. This war is seen as pitting those committed to nezâm, 'the Order' (i.e. 'the system' or 'the official order of things in the Islamic Republic'), against those who are not committed, and can variously be branded counter-revolutionaries (zedd-e enqelâb), hypocrites (monâfeq) or those 'at war with God' (mohâreb). In a post-revolutionary country such as Iran, ideology of course plays a major role in the state conceptualization of nationhood, and even though Iranian politics generally have gone in the direction of pragmatism and moderation ever since the death of Ayatollah Khomeini in 1989, it still does.

Particularly with the recent wave of so-called osul-garâ ' $i$ or 'fundamentalism' (meaning a strive towards upholding the fundamental tenets of Khomeinism) commitment to state ideology is still a top demarcation marker on the red line cutting through the heterogenic landscape of Iranian politics, dividing it into khodi ('those who are from the Self' or 'those who are with us') and gheyr-e khodi ('those who are against us'). Indeed, the equalling of being a good Muslim with being a good revolutionary with being a good Iranian is still a major factor in state ideology and thus a focus of the statecontrolled process of exclusion and inclusion. Using these two categories as prisms, I will proceed to look at the official response to these two examples of unrest as symbolic assertions defining the limits of Iranian nationhood.

\section{The State of Iran: Territorial integrity}

In both cases officials and media used much energy and space in presenting the roots of unrest, or at least the intensification of the unrest, as the result of foreign meddling. Regarding the Ahvaz unrest, Interior Minister Musavi-Lari claimed that the disturbances were a result of a 'conspiracy', and that 'foreign agents' ( 'avâmel-e borunmarzi) were involved in fanning the riots (Kayhân 2005a). A headline in the state-run Kayhân daily read: 'The hands of foreigners exposed in the Khuzestan events', and in the article, it was stated that the Ministry of Intelligence had identified 'the dirty hands of disorder (dast-hâ-ye nâ-pâk-e fetne)' in Khuzestan, that is, the instigators of the unrest, and arrested the culprits (Kayhân 2005c). Indeed, the Minister was quoted as saying that there is no 'domestic opposition capable of creating unrest' in Iran (Âftâb-e yazd 2005). The 'foreign agents' are generally classified as being a) British or associated to Great Britain, b) 'Zionists', i.e. pro-Israel forces; c) American or somehow allied to the US; d) members of the exiled opposition group Mujâhedin-e khalq; e) supporters of pan-Arabism, Ba'thism or followers of Saddam Hussein; or, f) Royalist supporters of a restoration of the Iranian monarchy. All of these classifications have their own backgrounds, and the first category - the British, who are accused of following their Imperialist agenda in Iran (Kayhân 2005d) - are perhaps the most 
significant of the alleged culprits in the coverage. This is due to their history of involvement and manipulation in this area and its tribal structures, and particularly to historic, British interests in the Iranian oil industry. Indeed, much speculation centred on the resources of the province, and Kayhân quoted a top-ranking official as stating that there would be an investigation into the possible role of 'the Zionist company Shell' in the events. It was stated that Shell had in recent years made many investments in Khuzestan, and had 'nurtured extensive relations to social and political centres' (Kayhân 2005b). At the bottom of these accusations lay the fear that foreign powers would want Khuzestan to secede from Iran, and thus deprive Iran of its most valuable source of income as well as a part of the country that many Iranians see as a cradle of their culture and civilization.

Officials also claimed that pan-Arabists, and particularly supporters of Saddam Hussein, were behind the unrest. It was stated that 'Arab intellectuals and elites unfortunately utilize the Ba'thist rhetoric' (Bâztâb 2005b) and the Minister of Intelligence, Ayatollah Dorri-Najafabadi, said that 'the agents' behind the Khuzestan unrest were people who: ... carried out serious bombings in the time of Saddam [Hussein], perpetrated crimes in Khuzestan and caused the martyring of many of our Arab compatriots ... "Currently, [the Arab separatists] have become refugees in an asylum provided by espionage agencies in [Europe], and with the help of [these espionage agencies] they are instigating separatism and unrest ..." (Fârs 2005b).

In particular, the Arab-language TV-network Al-Jazeera was targeted for its role in the unrest, and as a result the Tehran offices of this Qatar-based network were closed. It was stated by officials that Al-Jazeera was a 'propaganda loudspeaker for a marginalized separatist group' and that it had 'offended the territorial integrity of Iran' (Bâztâb 2005a). Arabs are sometimes considered an enemy among Iranians, who have a complex relationship to their neighbours. Indeed, scholars have pointed out the ambiguous love/hate-relationship, in which many Iranians scorn the Arabs for having a 'low' culture, and there is a sense among some Iranians of having been violated by the Arab invasions in the $7^{\text {th }}$ Century. This is of course a paradox, since these same invasions brought with them Islam, which is an undisputed main marker of identity among the majority of Iranians. At the same time, the 'Arab foe' is evoked in order to bring back to the Iranian public mind the eight-year war with Iraq, which was by all accounts the most significant and traumatic event in post-revolutionary Iranian history. Last but not least, some newspapers stated that the agents behind the unrest insisted 'that the Persian Gulf is not the Persian Gulf' (Fârs 2005a). The issue of the Persian Gulf being co-named the Arab Gulf on the 2004 National Geographic map caused uproar among Iranians and became a focus of nationalists inside and outside Iran, and was used by state officials as evidence of Western powers' ignorant attitude towards Iranian history and culture.

In relation to the Tabriz unrest, it should first be stated that officials tended to be very careful in singling out the 'unacceptable' and threatening elements in the unrest from the 'acceptable' and legitimate protesters. As mentioned earlier, the Azerbaijanis are a much bigger ethnic group than Arabs and have a larger share of and stake in the ruling 
elite. Thus, MPs from the Azerbaijan provinces were able to voice their concern about the caricature and the racist mentality allegedly behind it, and with the 'lack of attention' paid to socio-economic and developmental problems in Azerbaijani areas of Iran (Aftâb news 2005). However, the same MPs also stressed that the "people of Azerbaijan have separated their lines from those of the opportunists [forsat-talabân]' and that 'separatism' [tajziye-talabi] did 'not carry any meaning or sense' among the Azerbaijanis of Iran ( $i b i d)$. Throughout modern Iranian history, political leaders have been wary of any sign of separatism among the ethnic minorities, also vis-à-vis the Azerbaijanis. In particular, officials in the Islamic Republic were worried that the ethnic awakening that followed the 1991 declaration of an independent Azerbaijan in the former Soviet Union would spill over the Aras River and into Iran. While there have been increased cultural bonding across the border and while recent years have brought about a renewed interest in Azerbaijani culture and language in Iran, separatist groups do not seem to enjoy wide recognition. Indeed, there is general consensus among scholars that Iranian Azerbaijanis by and large consider themselves a part of the Iranian nation (Higgins 1984, Ahmadi 1999, Atabaki 2005 - the major exception being Schaffer 2002). Yet, as the following quotes show, politicians did 'remind' the Azerbaijanis about the possibility of their legitimate cause being hi-jacked during the unrest by foreign agents and proponents of 'Pan-Turkism', which in official terminology equals separatism. In Kayhân an articulated differentiation between what could be accepted and what is clearly not accepted was made:

From [the city of] Zanjan it is also reported that [during demonstrations] slogans were distorted towards pan-Turkic and ethno-nationalist slogans, as if the newspaper caricature was simply an excuse for some people to create unrest and riots. In this situation, some demonstrators confronted riot-making elements (Kayhân 2006a).

Note that it is implied that 'acceptable' protesters themselves confronted 'unacceptable' protesters. An MP from East Azerbaijan Province stated that there had been 'enough protests' and that the people should now be aware of 'certain suspicious actions' (IRNA 2006a). In other words, the 'legitimate' outrage against the caricature had found its peak, and from then on any sign of unrest would be considered the work of separatists or foreign agents.

However, as indicated earlier, the response of officials was two-pronged, and in both cases much energy was used on portraying national unity in Iran and emphasizing signs of this unity amidst the unrest. As an example, the 'Iraq card' was also played as a means of reminding the Khuzestanis of their much-celebrated resistance to Saddam's invasion in the early 1980s. As an example, the Interior Minister, utilizing the symbolism of a family united against an external threat, stated that 'the Khuzestani sisters and brothers, who have solemnly spent eight years of heroic defence [in the IranIraq War]' had shown that 'these conspiracies will not bear fruit' (Kayhân 2005a). Likewise, then Defence Minister Admiral Sham 'khani pointed out the Khuzestani Arabs' record of 'proud resistance' to Hussein, and he expressed concern for the socioeconomic problems of the area (Fârs 2005a). In particular, he stated that Khuzestan 'suffered a great loss and destruction' during the war with Iraq, and that 'problems arising here from must be solved' (ibid). This is in fact recognition of what 
was accepted in the ruling elite as being the major reason to the widespread riots, that is, unemployment and economical marginalization, rather than a wish for autonomy or ethnic rights. Furthermore, Sham'khani - himself an ethnic Arab - stated:

"The Order [of the Islamic Republic] is not worried about the borders [between]

Khuzestan [and Iraq], and that is because of the presence of the Khuzestani

Arabs. The central core of [the Republic] places no kind of limitation on Arab

people's advancement, and there is no boundary for our progress within the administrative system and the armed forces except for the limitations of our own capabilities" (Irân 2005b).

During the Tabriz unrest, officials also underscored the egalitarianism of the political system and the multi-ethnic unity, and they repeatedly stated that Azerbaijan historically and culturally had been a part of Iran, and that Azerbaijanis play an important role in Iranian society. As an example, key conservative and chairman of the Parliament Haddad-'Adel stated:

... "The people of Azerbaijan have always been known for their patriotism [vatan-khâhi] and alertness ... The people of Azerbaijan know that one of the conspiracies that the enemies have overtly declared is [to sow] discord, [Azerbaijanis] themselves will take their precautions, and this issue will, as other instances [of unrest], end to the benefit of the national unity [vahdat-e melli]" (IRNA 2006b).

In Kayhân, the high-ranking cleric and former president, Ayatollah Hashemi Rafsanjani was quoted as saying that 'damaging national unity is treason' while praising Iran's multi-cultural mosaic:

"Cultural diversity and its role in national unity is one of the complicated issues of our homeland because today ethnic and regional feelings are a good motive for creating discord ..." ... [Rafsanjani] recognized love for the homeland, the Persian language and alphabet alongside respect for ethnic and tribal languages and alphabets, and Islam as the best capacities and assets for national unity ... and added: "In the shade of Islam, national unity can undoubtedly be protected and strengthened ... If tribes and ethnic groups feel injustice, the elements of strengthening national unity will become weak." (Kayhân 2006c).

With these and other statements it is clear that the 'territorial integrity' issue becomes closely related to the second, that of 'ideological commitment'.

\section{The Order of the State: Ideology}

Officials used their response to underpin the view that loyalty towards state ideology was and is an important requisite for inclusion within the sanctioned limits of acceptable behaviour and thought. In relation to the Ahvaz unrest, some officials and newspapers stated that the forged letter that sparked the unrest had been circulated by 'counterrevolutionary agents' ('avâmel-e zedd-e enqelâb; see for example Kayhân 2005a). This is a term that has been in use since the revolution to denote any opposition to the Khomeinist line, i.e. anyone lacking commitment to the state ideology. The label 'counter-revolutionary' has thus been used to condemn student protesters, reformists 
and human rights advocates among others. Another very telling statement by Sham'khani read as follows:

"[The leaders of] The Holy Order of the Islamic Republic of Iran pay special attention to the Arab tribes, and without having any problems with these, [they] recognize them as being among the ethnic groups most loyal to the Islamic Revolution" (Fârs 2005a).

The Holy Order is a reference to the ideological conceptualization of the Islamic Republic being based on the Khomeinist principle of 'Rule of the Supreme Religious Jurisprudent' [velayat-e faqih], and thus to the theological legitimacy of the state. In other words, being loyal to the Revolution means being loyal to the Order of the Islamic Republic and to God, and thus, being a good Muslim equals being a loyal citizen of Iran. As an example of this, in his testimonial to the loyalty of Iranian Arabs, Sham'khani gave the people of Khuzestan distinctive religious-ideological credentials:

"The Arabs of Khuzestan have outstanding, excellent and unique credentials in defending the revolution, Islam, the clergy, the seyyeds [descendents of the Prophet Mohammad], Shiism and the country ... There are no Hypocrites [monâfeq] or counter-revolutionaries among the Arabs; the Arabs of Khuzestan will not cease their practice of Shiite Islam, and they will not act against a government which is Shiite" (Irân 2005).

This is particularly interesting, as the term monâfeq is a Koranic reference (those who pretend to have faith), which also has great importance in the Shiite symbolical universe (where Sunnis are portrayed as Hypocrites who refused to accept the rightful leadership of Imam Ali and his lineage) and in the Islamist discourse of Khomeini, who utilized it against his enemies. For example, monâfeq was used during the war to signify Saddam Hussein as a traitor to Islam, and today the term generally denotes Mojâhedin-e khalq, the Iranian opposition group in exile. Furthermore, by stressing the Shiite creed of Khuzestani Arabs, Sham'khani and other officials uses the Sunni-Shiite split as another layer of bonds between Iran and (most of) its Arab minority, and another layer of distance between the Arab minority in Iran and the wider Arab world, which is overwhelmingly Sunni. This is a card that the state was not able to use in its response to the 2005-7 ethnic unrest in Baluchistan and among the Kurds, who are mostly Sunnis and therefore a sort of 'double' minority - but a card that it did not hesitate to use towards the Arabs.

In the Tabriz unrest, one MP mentioned that 'Azerbaijan is awake and supports the revolution, the Order, the Leadership and its own culture' (Aftâb 2006). Note how the main ideological pillars of the Islamic Republic - the revolution, the Order of the Islamic Republic and the Supreme Leadership of Grand Ayatollah Khamene' $i$ - is mentioned first, and the Azerbaijani culture last. This statement can thus be viewed as the prioritization of loyalty as promoted by the power establishment: Loyalty to the religious-political system is (or should be) more important than loyalty to local, ethnic culture in shaping the identity of an Iranian citizen. The following three examples illustrate how politicians emphasize the religious-ideological mission of the revolution and how they intertwine it with the issue of territorial integrity: 
... "Some identity-less people still do not want to or cannot accept that Azerbaijani-speakers throughout the history of Irân-zamin ['Iran-land'] have held a great stake in the Iranian nation ... Today... the sworn enemies of the Order strives to place this tribe [i.e. the Azerbaijanis] in opposition to the Order, but they should know that Iran's Azerbaijanis are an inseparable part of Iran, and they will never give a chance to opportunists" (Kayhân 2006d).

... "All of the people are part of Islamic Iran and on a profound mission in the world of today, and must join together hand in hand in order to reach revolutionary and Islamic objectives ... The Iranian nation will never forget its original objectives as a result of the actions of some malicious people" (IRNA 2006a).

... "The people of Iran are united in the shade of Islam, and as always, Azerbaijan supports Islam, the Revolution and Iran ... God permitting [and] with the effort of all, unity and solidarity will be protected despite the wishes of foreigners" (Kayhân 2006e).

In both Ahvaz and Tabriz, huge 'National Unity' rallies were organized after the riots. While the rally in Tabriz did demand a reprimand of the cartoonist and the newspaper that brought the caricature, the main theme - at least according to Kayhân newspaper was the multi-cultural unity of Iran, and the people's commitment to the revolution. Kayhân (2006a) cited following slogans at the parade: 'Khuni ke dar rag-e mâ-st, hediye be rahbar-e mâ-st' (The blood in our veins is a present for our Leader) and 'Âzarbâyjân-e jânbâz, enqelâb'dân âyrilmâz' (The self-sacrificing Azerbaijan will never part from the Revolution). Note that the second slogan was in Azerbaijani Turkish while the first was in Persian.

Reformism and alternative interpretations of Islam, pro-democratic movements and now also ethnic unrest are perceived by the Iranian leaders as a threat to their revolutionary ideology and thus to the legitimacy of their rule. It is clear that state-sponsored Iranian nationalism is closely interlinked with the religious tenets of the revolution, and that the word mellat (nation) carries potent religious meaning and symbolism. Paul has stated "the very notion of "nation", in Persian, cannot be clearly detached from the religious sphere' and that 'Iranians cannot even think of, or "imagine", themselves as a political community in purely secular terms' (1999:194). Indeed, there is no doubt that the issues of religious commitment and political patriotism are very closely related in the state discourse, as the above examples have illustrated, and that loyalty to 'the Order' is portrayed as the expression of the Iranian people's will, and similarly, that threats to 'the Order' are perceived as being the work of foreigners and those not committed to an imagined historical destiny of Iran.

\section{Conclusion}

The cases of ethnic unrest portrayed in this article points to an amplified ethnic awareness amongst Iran's many minorities. This awareness has led to an increased attention from politicians as witnessed during election campaigns and has also meant that ethnic identities are no longer tabooed and cannot be ignored by the state apparatus. At the same time, the reactions of Iran's rulers to the ethnic unrest described above also reflect the fact that they view these developments as a potential threat to the Islamic 
Republic and the Iranian nation-state; and that in their condemnation of certain proponents of ethnic issues and in their expressions of sympathy and understanding with others, they reflect an internal accord in the power establishment on the boundaries and limits for political behaviour and national identity. In this discourse, the Iranian leaders differentiate acceptable behaviour in terms of loyalty to the nation, the state and its ideology (the essence of 'Iranianness') from unacceptable behaviour in terms of threats to territorial integrity, lack of commitment to the revolution or even lack of identity ('un-Iranianness'). The threat is symbolically portrayed as a contamination, intrusion and violation of the territorial integrity, homeland sanctity and the 'family' of a multi-ethnic Iranian nation, and the antidote and defence is patriotic solidarity and unity on the revolutionary path. To the ruling elite, protecting the territorial integrity of an existing nation-state (and their place as leaders within it) has become at least as important as the propagation of internationalist idealism (6). To this end, Iran's leaders utilize in their discourse the two main pillars of Iranian cultural identity, that is, Islamic and national identity, and they evoke what is perceived in the broad populace as 'historical enemies' in condemning alleged threats to territorial integrity.

Thus, far from being that 'fundamentalist' or rigidly Islamist state that Iran is sometimes presented, the reality is that Iranian state ideology is much more complex, dynamic and even pragmatic. The Iranian state - like most other states - is flexible in both ideology and realpolitik, and can make either one fit to the practical necessities when external or internal forces or developments compels it to do so. Two examples of such developments, which are important to keep in mind when analyzing the two incidents of ethnic unrest discussed in this article, have been mentioned: the war with Iraq and the reformist wave in the late 1990s. The first event reminded the rulers - no matter how ideologically driven they were - that Iran is a nation-state and the revolution had to be first and foremost a national project. Thus, when a state official today refers to a particular ethnic group as 'always' having been vatan-khâh or 'patriotic', it implies that this ethnic group places its loyalty not only to a state, which is founded on revolutionary Islamism, but also to an 'eternal' and 'essential' Iranian state, bound together by an implicit notion of 'Iranianness'.

This apparently contradictory and multi-layered idea of nationhood is intricately connected not only to Iranian culture but also to the very structure of the state: The Islamic Republic is neither an exclusivist theocracy nor an inclusive democracy - it is something in between, or rather, some third kind of political entity that due to its peculiar combination of features can be deemed as unique. On one hand, it was founded on the idea of a borderless Muslim community and on the other it is today acutely concerned with threats to the borders of a clearly defined nation-state. Indeed, the idea of an Islamic 'republic' was a novel invention spawned by the dynamics of modernity with no precedence in Islamic history; and thus, the ambiguity of the word mellat as presented today legitimizes a double usage in political/religious rhetoric to denote both the (borderless, pre-state) Muslim community as well as the (legal-territorial, modern) Iranian nation-state. As Farhi has noted, this is the irony of a state using 'trans-national Islam to confirm Iran as a national project' (2008). The plasticity of semantics and symbolism is daily moulded and remoulded in a fashion that allows Iranian nationalism to be Islamist and Islamism to be Iranian nationalism. 
The second event - the reformist wave and the advent of a new opposition - meant that the rulers were reminded that democratic forces exist in Iran and that even within the ruling establishment some demanded reform. This meant that human, civil and minority rights - at times formulated in accordance to the 'Western' definition and at times 'naturalized' by equating them with traditional Islamic concepts - became a central part of the public debate, and that the ruling elite was forced to adopt and adapt these concepts into their vocabulary. While essentialist and exclusivist interpretations of Islam and Iranian nationhood play important roles in state ideology, this does not mean that the ruling establishment can resist incorporating democratic, civic or 'Western' ideals - at least in the rhetoric-symbolic layer of its discourse. The issue that remains to be seen is whether the rulers of Iran will be able to contain or co-opt the trans-national forces of ethno-nationalism (such as seen among Baluchis and Kurds) and the signs of ethnically based regional discontent (such as among the Azerbaijanis and Arabs), and whether they will implement reforms and grant increased power to minorities (just as their discourse of multi-cultural harmony stipulates), or whether these signs of discontent will in fact become what many in Iran obviously fear: a threat to the territorial integrity. As stated earlier, it becomes increasingly difficult to predict developments in a volatile region such as the Middle East, but Iranian rulers seem aware that they have at least one strong symbolic dimension to draw upon, that is, the fact that many Iranians imagine themselves as having 2.500 years of continuous history as a nation that can indeed accommodate and assimilate many different ethnic groups, languages and religions.

\section{Endnotes}

1) The official notion of nationalism in contemporary Iran cannot be presented as a clear-cut case within the framework of the classical dichotomy of Kohn (2005), which divides nationalisms into 'Western' (civic/territorial) and 'Eastern' (ethnic/cultural) conceptualizations, since it incorporates elements of both. Indeed, as Smith (1991) has pointed out, it is normal for most states and nations to incorporate elements of both sides. The Islamic Republic and the preceding Pahlavi state (1925-1978) developed within the frames of a pre-existing, nascent state founded in the $16^{\text {th }}$ Century, and thus well before the advent of modern nationalism (just as in the 'Western nation' in Kohn's theory). At the same time, the idea of a nation (mellat) in Persian is difficult to fit into Kohn's classification since the word convey the double meaning of the 'Iranian volk' as well as the 'Muslim community' in general (Paul 1999), according to the situation within which it is used. One defining historic development which constituted, in the words of Kohn, 'the formation of the future national state' (2005: 329), was the conversion to Shi' ism as the official state doctrine in the $16^{\text {th }}$ Century, which provided Iranian subjects with an identity that distinguished them from their Sunni neighbours. However, the word mellat was only to be used in its 'modern' or 'Western' sense from the Constitutional Revolution of 1905-11 onwards, when civic rights were introduced as a defining factor. In this respect Iranian nationalism could be viewed through Kohn's prism as an 'Eastern' development rather than 'Western'.

2) This is not to say that nationalism, in the shape of anti-Imperialism, antiAmericanism and Third Worldism, was not a driving force behind the Iranian 
Revolution of 1978-9, but rather that the Islamists suppressed and tabooed secular and liberal notions of nationalism after the revolution. While accepting the 'existence' of nationalism in the modern world, Khomeini would initially rather emphasize the supranational and global unity of Muslims as a much more important and constructive force than nationalism (see for example Baba'i-Zarech, 2005). However, in time, Khomeini's ideological resistance to nationalism and praise for internationalism would soften and change, and Mashayekhi, Menashri and others have noted the following signs of an increased nationalistic stand: How patriotic concepts such as mihan ('fatherland') gradually became more prominent in official rhetoric during the war with Iraq; how Khomeini referred to Persian as 'the language of the revolution' (rather than Arabic, the holy language of the Koran); how Khomeini defended the term 'The Persian Gulf' instead of a more neutral name; how the state sought to promote Persian culture in Central Asia; and last but not least, 'the regime's defence of the Persian language in its confrontations with ethnic minorities' (Mashayekhi, 1993: 112). In the words of Mashayekhi, these are all signs that 'the post-revolutionary socialist project of Third Worldist nationalism never stood on firm ground' (Mashayekhi, 1993: 112).

3 ) As this is probably the most sensitive issue in Iran today, proper research is scarce. For journalistic coverage of the issue see for example Tohidi (2006) or Farahmand (2005).

4) At the same time, however, Khomeini acknowledged the existence of ethnic groups and nations as a 'reality', and saw the defence of Iran's territorial integrity as an important part of the revolutionary struggle. See for example Toiserkhani (2005) and Baba'i-Zarech (2005)

5) Some might argue that this has been the case even from the beginning of the Islamic Republic's history; indeed, Khomeini himself stressed that in order to further the Islamic revolution, the territorial integrity of the Iranian nation-state had to be protected, thus implicitly giving national interest a sort of priority above the interest of the global ummah / ommat (see for example Baba'i-Zarech 2005 and Toyserkani, 2005).

\section{References}

Abrahamian, Ervand. 2005. 'Pârânoid dar siyâsat-e irân', transl. Mohammad Ebrahim Fattahi (ed.), Jostâr-hâ'i darbâre-ye te'ori-ye towte'e dar irân, Tehran: Nashr-e ney. Âftâb-e yazd (daily). 2005. 'Nâ-ârâmi dar ahvâz', 19 April. Âftâb (news agency). 2005. 'Goft-o-gu bâ nemâyandegân darbâre-ye havâdes-e âzarbayjân', 3 June: aftabnews.ir (Retrieved 5 June; no longer online).

Ahmadi, Hamid. 1999. Qowmiyyat va qowm-garâ'i dar irân, Tehran: Nashr-e Ney. Ahmadi, Hamid. 2008. 'The dilemma of national interest in the Islamic Republic of Iran' in Katouzian, Homa \& Shahidi, Hossein (eds.): Iran in the $21^{\text {st }}$ Century, Oxon: Routledge.

Amirahmadi, Hooshang. 1996. 'From Political Islam to Secular Nationalism', featured on http://www.iranian.com/Jan96/Opinion/SecularNationalism.html (Retrieved 11 March, 2008).

Ansari, Ali. 2006. Confronting Iran: The Failure of American Foreign Policy and the Roots of Mistrust. London: C Hurst \& Co. Publishers.

Atabaki, Touraj. 2005. 'Ethnic diversity and territorial integrity of Iran: Domestic harmony and regional challenges', Iranian Studies, 38:1, 23-44. 
Baba'i-Zarech, 'Ali-Mohammad. 2005. Ommat va mellat dar andishe-ye emâm khomeini (r.h.), Tehran: Markaz-e asnâd-e enqelâb-e eslâmi.

Bâztâb (news agency). 2005a. 'Al-jazire: az mâh-e 'asal bâ eslâh-talabân tâ boland-guye ekhtesâsi-ye tajziye-talabân', 18 April. Website no longer online.

Bâztâb. 2005b. 'Kâlbod-shekâfi-ye nâ-ârâmi dar khuzestân', 24 April.

Farahmand, Mehrdad (2005). 'Qowmiyyat-hâ-ye irâni va entekhâbât-e riyâsat-e jomhuri', BBC Persian.com, June 17.

Farhi, Farideh. 2008. 'Crafting a national identity amidst contentious politics in contemporary Iran' in Katouzian, Homa \& Shahidi, Hossein (eds.): Iran in the $21^{\text {st }}$ Century, Oxon: Routledge.

Fârs (news agency). 2005a. 'Bar-resi-ye masâ'el-e akhir-e ostân-e khuzestân dar jalase-ye sham 'khâni va mo 'tamedân-e 'arab-e khuzestân', 19 April: farsnews.com. Fârs (news agency). 2005b. ' Âmel-e asli-ye havâdes-e khuzestân dastgir shode', 5 May.

Higgins, Patricia J. 1984. 'Minority-state relations in contemporary Iran', Iranian Studies, 17:1, 37-71.

Irân (daily). 2005a. 'Fa'âliyat-e nemâyandegi-ye shabake-ye al-jazire dar irân be hâlat-e ta 'liq dar âmad', April 19: iran-newspaper.com.

Irân. 2005b. 'Ahvâz ârâm shod', 21 April.

Irân. 2005c. 'Namâyesh-e hambastegi-ye aqvâm-e irâni dar khuzestân', 23 April. ILNA (news agency). 2007. '15 nafar be ettehâm-e towzi'-e shabnâme-hâ-ye gheyr-e qânuni dar ostân-e âzarbâyjân-e sharqi bâzdâsht shode-and', 22 May: ilna.ir.

IRNA (news agency). 2006a. "Nemâyande-ye tabriz: qaziye-ye ruznâme-ye "irân" pâyân-yâfte talaqi mi-shavad', 22 May: irna.ir.

IRNA. 2006b. 'Haddâd- 'âdel: mardom-e âzarbâyjân movâzeb-e dast-hâ-ye nâ-pâk bâshand', 23 May.

Kayhân (daily). 2005a. 'Nâme-ye ja'li montaseb be daftar-e riyâsat-e jomhuri, dar ahvâz moshkel-sâz shod', 16 April: kayhannews.ir.

Kayhân. 2005b. 'Vazir-e keshvar: 'avâmel-e borun-marzi dar hâdese-ye ahvâz dekhâlat dâshtand', 18 April.

Kayhân. 2005c. 'Dast-e bigânegân dar havâdes-e khuzestân efshâ shod', 21 April.

Kayhân. 2005d. 'Naqsh-e engelis dar havâdes-e khuzestân', 25 April.

Kayhân. 2006a. 'E 'terâz be yek kârikâtur dar chand shahr be khoshunat keshide shod', 23 May.

Kayhân. 2006b. 'Hanuz ham towte 'e tavvahom ast?!?', 25 May.

Kayhân. 2006c. 'Hâshemi rafsanjâni: makhdush kardan-e hambastegi-ye melli khiyânat ast', 25 May.

Kayhân. 2006d. 'Maleki: Âzari-zabân-hâ hargez bahâne be dast-e forsat-talabân nemidahand', 25 May.

Kayhân. 2006e. 'Ra is-e majles dar pâsokh be ezhârât-e tahrik-âmiz-e a 'lami: mellat-e irân dar sâye-ye eslâm bâ ham motahhed hastand', 25 May.

Kohn, Hans. 2005 [1944]. The idea of nationalism: a study in its origins and background. New Jersey: Transaction Publishers.

Mashayekhi, Mehrdad. 1993. 'The Politics of Nationalism' in Farsoud, Samih and Mashayekhi, Mehrdad (eds.): Political Culture in the Islamic Republic. London:

Routledge. 
Menashri, David. 2001. Post-Revolutionary Politics in Iran. Religion, Society and Power. London and Portland, Oregon: Frank Cass Publishers.

Mirâs khabar (news agency). 2006. 'Darj-e matlab-e towhin-âmiz be âzari-zabân-hâ towte 'e-ye doshman ast', 21 May: via news.gooya.com (Retrieved 22 May; no longer online).

Paul, Ludwig. 1999. '”Iranian Nation” and Iranian-Islamic Revolutionary Ideology', Die Welt des Islams, 39:2, 183-217.

Ram, Haggay. 2000. 'The immemorial Iranian nation? School textbooks and historical memory in post-revolutionary Iran', Nations and Nationalism, 6: 1, 67-90.

Takeyh, Ray. 2006. Hidden Iran: Paradox and Power in the Islamic Republic, New York: Henry Holt/Times Books.

Schaffer, Brenda. 2002. Borders and Brethren: Iran and the Challenge of Azerbaijani Identity. Cambridge, Massachusetts and London, UK: The MIT Press.

Smith, Anthony. 1991. National Identity, Reno: University of Nevada Press.

Tohidi, Nayereh. 2006. 'Iran: regionalism, ethnicity and democracy', featured on http://www.opendemocracy.net/democracy-irandemocracy/regionalism_3695.jsp (Retrieved on March 11, 2008).

Toyserkani, Yahya Fowzi. 2005. Emâm khomeini va hoviyyat-e melli, Tehran: Markaz-e asnâd-e enqelâb-e eslâmi. 